\title{
Robin Romm. 2009. The mercy papers: A memoir of three weeks
}

\author{
New York: Scribner, ISBN 1416567887, 224 pp
}

\author{
Felicia Cohn
}

Received: 22 May 2009 / Accepted: 27 July 2009 /Published online: 18 August 2009

(C) The Author(s) 2009. This article is published with open access at Springerlink.com

I wanted this book to make me cry. It didn't. In The Mercy Papers Robin Romm shares her experience of being called home to New York from graduate school at the University of California, Berkeley for her mother's final weeks of life. Flashbacks illuminate the nine years the family has been living with breast cancer, and the relationship between mother and daughter as well as other family members and friends. While Romm is devastated by her mother's illness, her dying, and her death, the story she tells is honest, angry, and very real, but not heart-rending. That it did not make me cry was both its greatest strength and most distressing weakness. So, why were there no tears?

First, the title prepared me for a different kind of story. I anticipated a story about mercy killing, euthanasia or assisted suicide, or at least the request for it. I imagined a compelling tale of a patient begging for mercy, an end to her misery, and the family's introspective search for meaning in the request. Instead, "Mercy" turns out to be the author's dog: "My mother is going to die.... I need a dog" (Romm 2009, 24). After much searching, she finds a puppy at the Merced County Animal Control which

F. Cohn $(\bowtie)$

School of Medicine, Educational Affairs,

University of California, Irvine,

Berk Hall, Medical Education Bldg 802,

Irvine, CA 92697, USA

e-mail: fcohn@uci.edu she names Merced, or Mercy, for short. The dog provides comfort and some comic relief for both Romm and the reader. Perhaps ironically, it is the family's cat that is euthanized during the last weeks of the mother's life. While so preoccupied with the dying mother, the cat's death barely registers an emotional response. As for the human patient, Romm cannot even bear to provide pain medication, fearing it will expedite her mother's death. It is unclear how the dying woman feels about this herself; Romm writes about her mother's strength but not her emotions. When Romm finally does apply a fentanyl patch as her mother screams in pain on what turns out to be her last day, she is convinced not that she is providing much needed relief, but that she is killing her mother. That Romm is able to provide pain medication in her mother's last moments perhaps does infuse some unintended or subconscious meaning in the title, but Romm does not explore this. As with her need for a dog, the focus is not on a merciful death for her mother, but on what Romm needs to cope with the situation. The open expression of emotion, the guilt, the desire, the love, is compelling, and the expression of anger and fear is so overwhelming, that sadness is left behind, if not for Romm then for the reader.

Second, the book offers a disturbing rather than comforting and endearing perception of home hospice. Hospice was developed to make the end of life a bearable, if not a meaningful experience. Families generally report positive experiences (see, for example, 
Teno et al. 2004) - being prepared for the end, appreciation for the symptom management that allows for quality time with loved ones, support through illness and bereavement. Romm, however, suggests a dark side to hospice. She rails against its seeming standardization of the experience of dying. Of the hospice nurse, she says:

She's building a boat to sail my mother out. She has no interest in my mother's life, the thoughts she had, the cases she won, her family. Barb will build the boat of morphine and pillows and then I will have no mother and the days will be wordless and empty (Romm 2009, 3).

For Romm hospice is nothing but the vehicle taking her mother away. Among hospice's goals is family support through dying and bereavement. Romm graphically demonstrates that such support is not welcome to all: “I don't like your hospice thing at all. You walk into a house you don't know, into a family who's been living next to death for years, and you tell us what to think of it. How dare you" (108). Outrage may redirect (or misdirect?) the emotions both Romm and the reader are feeling, again eclipsing sorrow.

Third, while the book is fundamentally about loss, it reads more as a tribute to selfishness. In her hostility to all things hospice, Romm ignores that its primary purpose is to attend to the patient's needs. How her mother felt about the hospice care and whether it was medically beneficial is disregarded in the book. Romm appears to blame hospice for her mother's condition, repeatedly expressing concern about her mother's hazy state, without stopping to consider that the "haze" may have been what her mother needed. Instead, hospice is the obstacle interfering with Romm's need for a living, vital, healthy mother: "Now after she takes the pills, I understand I won't be able to reach the mom I used to know" ( 80). Further, she refers to hospice as "nurse-inflicted homicide", with drugs that "will speed us to the end" slipped to the patient without asking (109). The nurse did not seek Romm's permission to treat; Romm is not her patient. The reader is not privy to what the patient asks for or consents to from this nurse. Romm does not acquiesce to the politically correct, supportive daughter role. When the hospice nurse asks her to tell her mother that she will be okay after her mother dies, Romm rebels. She responds with rage, even telling her mother "I know it is selfish,...But I can't tell you it's okay to die. I won't be okay" (110). Despite her mother's response, "I dun need your permission", Romm continues on her mission, "more life, at any cost" (111). It is unclear if the book is intended to be cathartic for the author; regardless she writes about her experience of her mother's death. Though her mother's death occasions the written reflection, the book is really about Romm as she lives through a tragic experience. The wellexecuted prose (what else would one expect from an assistant professor of creative writing and literature?) is impressively egocentric. Perhaps this helps the reader understand why the book was named in honor of her dog instead of in memory of her mother.

Among the tasks of a reviewer is the determination of appropriate audience. In this regard, I continue to struggle. There are individuals to whom I would recommend this book. Categorically, however, I might only commend this quick read to those already working in end-of-life care - the health care professionals, hospice workers, and researchers already engaged in the practice and study of dying and death. The book provides powerful insight into one way that family members may deal with dying. This may serve to remind practitioners that dying affects not just the patient in profound ways and to enhance the empathic and differentiated response to the needs of family members.

I might also offer this book to family members of some of my dying patients. It may help them sort out their own feelings, help them to recognize they may not be alone in what they are feeling. For some this may be comforting, though to others agonizing. Romm gives life to the stages of grief -anger, guilt, bargaining, to all but acceptancein a way that Elizabeth Kübler-Ross does not (Kübler-Ross 1969). She offers no false hope, no supportive shoulder, but some may benefit from her raw honesty, particularly if sharing their news of a dying loved one is otherwise regularly met with false optimism and platitudes about the meaning of death. However, I am not sure I would want my dying loved one to spy this book on my bedside table. Not all mothers (or fathers, siblings or other loved ones) can be as strong as Romm's mother appeared to be in the face of her child's distress. 
Romm concludes the book with blank pages. She accused hospice care providers of telling her what she was supposed to feel, and she does not wish to similarly impose her feelings on her readers. It seems she is also inviting the reader to write his/her own ending. Perhaps therein lies the greatest value of the book: the recognition that we each will experience dying and death differently, and that those experiences should be respected, if not appreciated. "Loss goes on and on", Romm writes, "written on every day that will follow" (Romm 2009, 194). Her loss informs her identity, her writing, and her life. She seeks meaning in loss itself, not the experience of illness or healing after death. In her afterword, she claims her mother "would have wanted her journey to be something others could use" (209). But in the end, it is not her mother's journey but Romm's own that is really the subject of the book, though it is not so much a journey as a revolt.

And I realize now, in the dark room, that I am not ready, that I will never be ready, that her death will change me even though I've understood that it's been coming for nine years. And all the changes won't be hopeful...some of the changes will be only pain (83).

Open Access This article is distributed under the terms of the Creative Commons Attribution Noncommercial License which permits any noncommercial use, distribution, and reproduction in any medium, provided the original author(s) and source are credited.

\section{References}

Kübler-Ross, E. 1969. On death \& dying. New York: Simon \& Schuster/Touchstone.

Romm, R. 2009. The mercy paper's: A memoir of three weeks. New York: Scribner.

Teno, J.M., B.R. Clarridge, V. Casey, L.C. Welch, T. Wetle, R. Shield, and V. Mor. 2004. Family perspectives on end-oflife care at the last place of care. JAMA 291: 88-93. 